\section{Tropical Journal of Pathology and Microbiology}

2021 Volume 7 Number 3 July-August

\title{
Serum adiponectin among different stages of type 2 diabetes mellitus patients
}

\author{
Rashmi G S Basavaraj ${ }^{1}$, Ravikumar Malladad ${ }^{2 *}$ \\ DOI: https://doi.org/10.17511/jopm.2021.i04.01
}

${ }^{1}$ Rashmi G S Basavaraj, Consultant Pathologist, , Malladad Rudramma Memorial Hospital, Haveri, Karnataka, India.

2* Ravikumar Malladad, Consultant Physician, , Malladad Rudramma Memorial Hospital, Haveri, Karnataka, India.

\begin{abstract}
Background: Type 2 diabetes mellitus is a chronic metabolic disorder that leads to micro and macrovascular complications. Nephropathy is the most common microvascular complication. For diagnosis of nephropathy in T2DM patients by using urinary albumin, this is not a sensitive and specific biomarker because it is elevated in other conditions. we aimed to evaluate the serum adiponectin for early detection of nephropathy in patients with type 2 diabetes mellitus. Methods: A total of 60 subjects were included in the present study and further subdivided into 30 patients T2DM with normoalbuminuria, 30 patients with microalbuminuria. All the patients were included after obtaining institutional ethical permission and consent forms. Blood and urine samples were collected from all the subjects and proceed with further analysis. Appropriate statistical analyses were used for different types of data analysis. Results: Increased levels of FBS, PPBS, HbA1C and serum adiponectin were observed in two groups of T2DM patients. Statistically elevated levels of serum Urea, Creatinine and Uric acid levels were observed in patients T2DM with microalbuminuria when compared to T2DM with normoalbuminuria. The serum adiponectin was positively correlated with FBS, PPBS, HbA1C, Urea, Creatinine, Uric Acid and Urinary Albumin in patients with two groups of T2DM. Conclusion: This study concluded that measuring the serum adiponectin levels may be useful for the early detection of nephropathy in patients with T2DM.
\end{abstract}

Keywords: Type 2 Diabetes Mellitus, HbA1C, Adiponectin and Urine Albumin

Corresponding Author

Ravikumar Malladad, Consultant Physician, Malladad Rudramma Memorial Hospital, Haveri, Karnataka, India.

Email: rashmimallada@gmail.com
How to Cite this Article

To Browse

Rashmi G S Basavaraj, Ravikumar Malladad. Serum adiponectin among different stages of type 2 diabetes mellitus patients. Trop J Pathol Microbiol. $2021 ; 7(3): 155-161$.

Available From

https://pathology.medresearch.in/index.php/jopm/ar ticle/view/560

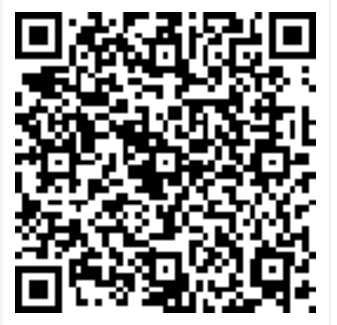

Manuscript Received 2021-06-24

Conflict of Interest No
Review Round 1 2021-07-04

Funding $\mathrm{Nil}$

Review Round 2
2021-07-20
Ethical Approval
Yes

Review Round 2 Yes

Review Round 3
2021-08-02
Plagiarism X-checker
$6 \%$

Accepted 2021-08-18

Note

(c) 2021 by Rashmi G S Basavaraj, Ravikumar Malladad and Published by Siddharth Health Research and Social Welfare Society. This is an Open Access article licensed under a Creative Commons Attribution 4.0 International License https://creativecommons.org/licenses/by/4.0/ unported [CC BY 4.0]. 


\section{Introduction}

Type 2 diabetes mellitus is a chronic metabolic disease due to both genetic and environmental factors play an important role in insulin resistance. In this condition, $\beta$-cell function in the pancreas declines gradually over some time before the onset of clinical hyperglycemia. Several mechanisms have been proposed for insulin resistance, including increased non-esterified fatty acids, inflammatory cytokines, adipokines, and mitochondrial dysfunction, whereas glucotoxicity, lipotoxicity and amyloid formation have been attributed to be responsible for $\beta$-cell dysfunction [1-2]. Diabetic nephropathy (DN) is one of the major and most common microvascular complications in patients with T2DM and develops as progressive kidney disease as a result of angiopathy of capillaries in the renal glomeruli and causes nephrotic syndrome and diffuse glomerulosclerosis [2-4]. DN is presently the single commonest cause of end-stage kidney failure worldwide and is acknowledged as an independent risk factor for cardiovascular disease [5]. Microalbuminuria is defined as albumin excretion of $30-229 \mathrm{mg} / 24$ hours and proteinuria as protein excretion of $>500 \mathrm{mg}$ in 24 hours in the setting of diabetes. Screening for diabetic nephropathy may be accomplished by either a 24-hour urine collection or a spot urine measurement of microalbumin [6-7]. Poor glycemic control is identified as a critical etiological factor for nephropathy in diabetes patients. Studies have shown that high HbA1c levels which are reflective of poor metabolic control are associated with an increased incidence of nephropathy [8]. In addition, hyperglycemia associated metabolic complications such as the formation of advanced glycation end products (AGEs) also contributes to renal disease in diabetes [9]. AGEs are formed as a result of the irreversible attachment of reducing sugars to the amino acids of proteins and are proposed to be involved in the pathophysiological mechanisms underlying diabetic nephropathy through the generation of oxidative stress, increased production of cytokines and growth factors and also by interacting with the renin-angiotensin-aldosterone system [10-11].

Adiponectin is an adipocytokine and it has antiinflammatory, antiatherogenic, and antidiabetic properties. It is also normally present on the endothelium and in the smooth muscle cells of intrarenal arteries and on the endothelium of glomerular and peritubular capillaries.
Circulating adiponectin exists mainly in three isoforms which include a low molecular weight trimeric form (LMW), a hexameric middle molecular form (MMW) and a high molecular weight form (HMW) consisting of 12-36 monomers; globular form and full-length form are the minor circulating fractions of adiponectin [12-13]. The mean plasma concentration of adiponectin was reported to be higher compared to other adipocytokines such as leptin and IL-6, ranging from $5-30 \mathrm{mg} / \mathrm{L}$ or $5-30$ $\mu \mathrm{g} / \mathrm{mL}$, accounting for about $0.01 \%$ of all plasma proteins in humans [14]. The plasma half-life of adiponectin is seventy-five minutes and the protein is mainly cleared by the liver and also kidneys. The high molecular weight form has the slowest clearance rate and relatively constant serum levels. Adiponectin acts through three cellular receptors namely, Adiponectin receptor 1 (AdipoR1), Adiponectin receptor 2 (AdipoR2), and T-cadherin. Adiponectin plays an important role in metabolic regulation and energy homeostasis, mainly through its effects on carbohydrate and lipid metabolism [15]. Adiponectin inhibits hepatic gluconeogenesis by inhibiting genes involved in glucose production thereby decreasing glucose levels.

The glucose-lowering effect appears to be independent of insulin. Through its local action in key metabolic tissues, adiponectin promotes insulin sensitization and therefore improves whole-body energy homeostasis. On lipids, adiponectin increases $\beta$-oxidation of fatty acids in skeletal muscle and suppresses lipid accumulation in the liver. Adiponectin also exerts strong protection against several pathological events in various cells by suppressing cell death, inhibiting inflammation, and enhancing cell survival [16]. Though mainly synthesized and secreted from adipocytes, plasma adiponectin levels were found to be decreased with increasing visceral obesity and correlated with insulin resistance and the development of type 2 diabetes. The adiponectin receptor AdipoR1 was found to be expressed on endothelial cells, podocytes, mesangial cells, Bowman's capsular epithelial cells of the glomerulus, and also by the proximal tubular cells [17]. AdipoR1 has a greater affinity for the globular form of adiponectin and can cause activation of the AMPK pathway. AMPK is considered to be required for the maintenance of renal physiology. Activation of AMPK results in the activation of energy-generating processes while inhibiting energy-consuming processes and the generation of free radicals [18]. 
These beneficial effects of adiponectin on podocytes reduce the permeability of podocytes to albumin and thus protect against the development of albuminuria. The present study is to determine the serum adiponectin among different stages of type 2 diabetes mellitus patients.

\section{Materials and Methods}

Settings: This study was conducted in the Department of Pathology at the Institute of Medical Science, Karnataka.

Duration and Type of The study: This is a crosssectional observational study conducted from April 2017- Feb 2020.

Sampling Methods: A total of 60 patients were diagnosed with type 2 diabetes mellitus as per American Diabetes Association (ADA) criteria. 30 Normoalbuminuria is defined as urinary albumin to creatinine ratio (ACR) $<30 \mathrm{mg} / \mathrm{g}$ creatinine; 30 microalbuminuria is defined as ACR in the range of $30-299 \mathrm{mg} / \mathrm{g}$ creatinine.

Sample Size: 60 Cases

Inclusion Criteria: All the subjects Age $>30$ years, Patients diagnosed with type 2 Diabetes mellitus based on ADA criteria in different stages of nephropathy.

Exclusion Criteria: Type 1 Diabetes Mellitus, NonDiabetic Renal Disease, Urinary Tract Infections, Individuals on thiazolidinediones, anti-inflammatory and immunosuppressive drugs, Thyroid and liver disease, Macrovascular complications such as cardiovascular, cerebrovascular and peripheral vascular diseases, Active inflammatory disease excluded from this study.

Data collection and Procedures: Four (4) $\mathrm{mL}$ of fasting venous blood sample was collected from all the subjects into two tubes: $1 \mathrm{~mL}$ into a tube containing (anti glycolytic and anticoagulant), and 3 $\mathrm{mL}$ into a plain tube. Plasma samples were separated immediately and plain samples were allowed to clot and separated by centrifugation at $3000 \mathrm{rpm}$ for $15 \mathrm{~min}$.

The separated samples were transferred into appropriately labelled aliquots and stored at $-80 \mathrm{OC}$ until biochemical analysis was done. Spot urine sample was collected along with the blood sample and was processed immediately for albumin and creatinine.
The FBS, PPBS, Urea, Creatinine, Uric acid, HbA1C and Urinary Albumin were analysed by using laboratory standard methods, serum adiponectin analysed ELISA Method.

Ethical considerations and Permission: All the subjects were recruited in the study after informed consent. The study was approved by the Institutional ethics committee.

Statistical Analysis: The data was checked for the difference in the adiponectin levels between patients and controls was analysed using unpaired two-tailed Student's t-test or Mann Whitney $U$ test as appropriate. The association between the variables was studied using Pearson or Spearman correlation analysis. Statistical analysis was performed using Microsoft Excel spreadsheets and SPSS for windows version 16.0. A p-value $<0.05$ was considered statistically significant.

\section{Results}

Table 1 shows the data distribution among the two groups of type 2 diabetes mellitus significant difference was observed across the four groups for fasting blood sugar, postprandial blood sugar, glycated haemoglobin, serum adiponectin and urine albumin creatinine ratio. All the two groups of patients had significantly higher fasting blood sugar, post prandial blood sugar, blood urea, creatinine, uric acid, HbA1C, Urinary Albumin and serum adiponectin levels in patients T2DM with microalbuminuria when compared to T2DM with Normoalbuminuria $(p<0.0001 * *)$.

Table-1: Demographic characteristics and biochemical parameters studied in two groups of type 2 diabetes mellitus patients

\begin{tabular}{|l|l|l|}
\hline \multicolumn{1}{|c|}{ Parameter } & \multicolumn{1}{|c|}{$\begin{array}{c}\text { T2DM with } \\
\text { Normoalbuminuria }\end{array}$} & \multicolumn{1}{c|}{$\begin{array}{c}\text { T2DM with } \\
\text { Microalbuminuria }\end{array}$} \\
\hline Age (years) & $47.93 \pm 5.34$ & $52.80 \pm 5.99$ \\
\hline FBS (mg/dL) & $88.93 \pm 11.52$ & $185.67 \pm 74.92$ \\
\hline PPBS (mg/dL) & $124.69 \pm 44.14$ & $238.27 \pm 96.69$ \\
\hline Serum urea (mg/dL) & $33.87 \pm 12.37$ & $78.07 \pm 13.56$ \\
\hline $\begin{array}{l}\text { Serum creatinine } \\
\text { (mg/dL) }\end{array}$ & $1.01 \pm 0.19$ & $4.79 \pm 0.88$ \\
\hline $\begin{array}{l}\text { Serum Uric Acid } \\
\text { (mg/dL) }\end{array}$ & $4.23 \pm 2.27$ & $11.46 \pm 9.82$ \\
\hline HbA1C (\%) & $3.18 \pm 9.82$ & $10.32 \pm 8.70$ \\
\hline $\begin{array}{l}\text { Urinary Albuminuria } \\
\text { (mg/dL) }\end{array}$ & $15.70 \pm 5.47$ & $82.90 \pm 8.70$ \\
\hline $\begin{array}{l}\text { Serum Adiponectin } \\
\text { (ng/mL) }\end{array}$ & $12.79 \pm 0.88$ & $17.01 \pm 12.98$ \\
\hline
\end{tabular}


Table 2: Show the Pearson correlation between the two groups of T2DM patients. The serum adiponectin was positively correlated with plasma fasting blood sugar, postprandial blood sugar, serum urea, creatinine, uric acid and Urinary Albuminuria levels were in two groups of T2DM Patients.

Table 2: Shows the Pearson correlation analysis in between serum Adiponectin with other biochemical parameters among two groups of T2DM Patients

\begin{tabular}{|l|l|l|l|}
\hline Parameter & \multicolumn{1}{|c|}{ Name of The Parameters } & r value & P-value \\
\hline \multirow{4}{*}{} & Fasting Blood Sugar $(\mathrm{mg} / \mathrm{dL})$ & 0.164 & 0.079 \\
\cline { 2 - 4 } & Post Prandial Blood Sugar $(\mathrm{mg} / \mathrm{dL})$ & 0.079 & 0.854 \\
\cline { 2 - 5 } & Serum Urea $(\mathrm{mg} / \mathrm{dL})$ & 0.687 & $0.0001^{* *}$ \\
\cline { 2 - 5 } & Serum Creatinine $(\mathrm{mg} / \mathrm{dL})$ & 0.549 & $0.0001^{* *}$ \\
\cline { 2 - 5 } & Serum Uric Acid $(\mathrm{mg} / \mathrm{dL})$ & 0.637 & $0.0001^{* *}$ \\
\cline { 2 - 5 } & 0.289 & $0.0001^{* *}$ \\
\cline { 2 - 5 }$(\%)$ & 0.401 & $0.0001^{* *}$ \\
\hline
\end{tabular}

\section{Discussion}

Diabetic nephropathy, also known as diabetic kidney disease is one of the microvascular complications of diabetes mellitus that is characterized by the occurrence of persistent microalbuminuria, decreased renal function, hypertension and an increased risk of cardiovascular morbidity and mortality and is associated with type 1 or type 2 diabetes mellitus [19]. Diabetic nephropathy is the most common cause of end-stage renal disease and renal replacement therapy. Although the incidence of diabetic nephropathy is higher in type 1 diabetes, due to the continuing increase in the prevalence rates of type 2 diabetes along with decreased mortality rates from cardiovascular disease, patients with type 2 diabetes account for about one-third of all patients requiring renal replacement therapy Further, it is predicted that the number of type 2 diabetes patients requiring renal replacement therapy will The increased circulating adiponectin levels could be due to an increased adiponectin synthesis in adipose tissue and its secretion into the blood in an attempt to overcome the microvascular damage in the advanced stage of diabetic nephropathy [20-21]. Since recent times, the relationship between adiponectin and kidney function is gaining increasing recognition. However, the majority of studies exploring the relationship of adiponectin with renal function were conducted on diseased individuals. Monomers and dimers of adiponectin that are small enough to cross the glomerular filtration barrier were found to be excreted in the urine of healthy individuals [22].
Proximal and distal tubular cells and were shown to synthesize and excrete adiponectin. Moreover, adiponectin is also normally present on the endothelium and in the smooth muscle cells of intrarenal arteries and on the endothelium of glomerular and peritubular capillaries. adiponectin inhibited mesangial cell proliferation and expression of type IV collagen, laminin, and fibronectin thus suggesting its renoprotective effects thereby suppressing the development and progression of DN [23]. Sharma et al; have shown that adiponectin knockout mice had increased albuminuria that could be reversed by the administration of adiponectin, however, the same beneficial effect could not be extrapolated to the entire spectrum of diabetic nephropathy since the relationship between serum adiponectin levels and albuminuria was found to exhibit a biphasic pattern [24]. In patients with normoalbuminuria, adiponectin was found to have a negative association with albuminuria, on the other hand, in patients with more advanced albuminuria serum adiponectin levels correlated positively with albuminuria [25]. Accordingly, earlier studies have reported significantly higher adiponectin levels in the presence of advanced diabetic nephropathy. A recent study showed that plasma adiponectin levels increased significantly with the progression of diabetic nephropathy [26].

Similarly, another study reported that although serum adiponectin levels in the diabetic group did not show any significant difference as compared with the control group, the highest concentrations of adiponectin were observed in patients with macroalbuminuria when compared to those with normoalbuminuria and microalbuminuria, or the control group [27]. The serum total and HMW adiponectin levels correlated positively with the severity of diabetic nephropathy and retinopathy [28]. One more study found that diabetic patients with overt nephropathy had elevated serum levels of adiponectin that appear to be increased in proportion to the degree of renal tubular injury and tubulointerstitial inflammation [29]. According to them, the increase in circulating adiponectin in overt diabetic nephropathy patients might be a physiological response to mitigate renal tubular injury and to prevent the further progression of diabetic nephropathy through its anti-inflammation and anti-atherogenic effects [30]. They observed that both serum and urinary adiponectin levels were significantly increased in patients with overt diabetic nephropathy. 
Moreover, they have also observed a positive correlation between serum adiponectin and urine adiponectin levels in all patients of type 2 diabetes irrespective of the degree of diabetic nephropathy [31]. Thus, according to them, the increase in the serum adiponectin levels are caused by the increased synthesis in adipose tissue and secretion of the marker rather than reduced clearance due to impaired renal function [32]. They have also concluded that the reno protective role of adiponectin is mainly brought about by its effects on podocytes and is mediated by the AMPK pathway and also observed that overexpression of adiponectin in streptozotocin induced diabetics resulted in reduced proteinuria. Thus, these findings indicate that adiponectin exhibits renoprotective effects mainly through its action on podocytes [33]. Thus, findings of the present study indicate that serum adiponectin levels are increased in type 2 diabetes mellitus patients with Normo and microalbuminuria. Although adiponectin is known to protect against the development of proteinuria, the exact relationship between adiponectin and albuminuria appears to be complex and needs to be further evaluated. Moreover, adiponectin was also found to be involved in the beneficial effects observed with the medical treatment of albuminuria using angiotensin-converting enzyme inhibitors, angiotensin II receptor blockers (ARBs), Thiazolidinediones [34]. Previously one more study has shown that adiponectin reduces the degree of microalbuminuria and exhibits renal protective effects by improving endothelial dysfunction and uncoupling of the glomerular vascular endothelial growth factor (VEGF)-nitric oxide (NO) axis in streptozotocin-induced type 2 diabetic rats with early diabetic nephropathy [35]. Hence, understanding the pathophysiological relationship between adiponectin and albuminuria might help in elucidating the exact role played by this adipocytokine in the development of albuminuria in various clinical conditions such as type 2 diabetes mellitus. This has clinical implications in that besides being a marker of nephropathy, albuminuria is considered an important risk factor for cardiovascular disease in patients with diabetes mellitus.

\section{Conclusion}

The present study evaluated serum adiponectin concentrations in individuals with type 2 diabetes mellitus with normoalbuminuria, microalbuminuria.
The elevated levels of serum adiponectin in patients with type 2 diabetes with normoalbuminuria, before excretion of urinary microalbuminuria. Serum adiponectin concentration in the circulation is increased in patients with advanced diabetic nephropathy, thus suggesting its potential role in the pathophysiological process underlying the development of nephropathy which is characterized by albuminuria.

\section{What new this study adds to existing knowledge}

For diagnosis of nephropathy in T2DM Patients by using Urinary Microalbuminuria, but is not an accurate, sensitive and specific biomarker for early detection of nephropathy, by using serum adiponectin monitoring were useful for early detection, sensitive and specific biomarker for nephropathy in T2DM patients because it is elevating before excretion of urinary Microalbumin.

\section{Authors Contribution}

Dr. Rashmi GS Basavaraj, Data collection, Literature review, Manuscript preparation, Manuscript editing, Final approval. Dr. Ravikumar Malladad, Patients Selection, Collection of Samples, Data Analysis and Statistical analysis.

\section{Reference}

01. Stumvoll M, Goldstein BJ, van Haeften TW. Type 2 diabetes- principles of pathogenesis and therapy. Lancet. 2005 Apr 9-15;365(9467)1333-46. doi: 10.1016/S0140-6736(05)61032-X

[PubMed][Google Scholar]

02. American Diabetes Association. Erratum, Classification and diagnosis of diabetes, Sec 2, In Standards of Medical Care in Diabetes-2016. Diabetes Care. 2016;39(Suppl 1)S13-S22. Diabetes Care. 2016 Sep;39(9)1653. doi: 10.2337/dc16-er09 [Crossref][PubMed][Google Scholar]

03. Frier BM. Diabetes mellitus, 20 th ed, In- Boon A Colledge $R$ Davidson's Principles and practice of medicine. Churchill Living stone. 2006;805-48. [Crossref][PubMed][Google Scholar]

04. Gosmanov AR, Gosmanova EO, Dillard-Cannon E. Management of adult diabetic ketoacidosis. Diabetes Metab Syndr Obes. 2014 Jun 30;7;255-64. doi: 10.2147/DMSO.S50516 [Crossref][PubMed] [Google Scholar] 
05. Fowler, Michael J. "Microvascular and macrovascular complications of diabetes". Clinical diabetes. 26;2(2008)77-82. [Crossref][PubMed] [Google Scholar]

06. Ruggenenti P, Remuzzi G. Nephropathy of type 1 and type 2 diabetes- diverse pathophysiology, same treatment?. Nephrol Dial Transplant. 2000 Dec;15(12)1900-2. doi: 10.1093/ndt/15.12.1900 [Crossref][PubMed][Google Scholar]

07. Fukami K, Yamagishi S, Ueda S, Okuda S. Role of AGEs in diabetic nephropathy. Curr Pharm Des. 2008;14(10)946-52. doi: 10.2174/138161208784139710 [Crossref][PubMed] [Google Scholar]

08. Tziomalos K, Athyros VG. Diabetic NephropathyNew Risk Factors and Improvements in Diagnosis. Rev Diabet Stud. 2015 Spring-Summer;12(1-2)1108. doi: 10.1900/RDS.2015.12.110 [Crossref] [PubMed][Google Scholar]

09. Cao Z, Cooper ME. Pathogenesis of diabetic nephropathy. J Diabetes Investig. 2011 Aug 2;2(4)243-7. doi: 10.1111/j.20401124.2011.00131.x [Crossref][PubMed][Google Scholar]

10. Mezzano S, Aros C, Droguett A, Burgos ME, Ardiles $\mathrm{L}$, Flores $\mathrm{C}$, et al. NF-kappaB activation and overexpression of regulated genes in human diabetic nephropathy. Nephrol Dial Transplant. 2004 Oct;19(10)2505-12. doi: 10.1093/ndt/gfh207 [Crossref][PubMed][Google Scholar]

11. Dasu MR, Devaraj S, Park S, Jialal I. Increased toll-like receptor (TLR) activation and TLR ligands in recently diagnosed type 2 diabetic subjects. Diabetes Care. 2010 Apr;33(4)861-8. doi: 10.2337/dc09-1799 [Crossref][PubMed][Google Scholar]

12. Basi $S$, Fesler $\mathrm{P}$, Mimran A, Lewis JB. Microalbuminuria in type 2 diabetes and hypertension- a marker, treatment target, or innocent bystander?. Diabetes Care. 2008 Feb;31 Suppl 2;S194-201. doi: 10.2337/dc08-s249 [Crossref][PubMed][Google Scholar]

13. Sun $Y$, Xun $K$, Wang $C$, Zhao H, Bi H, Chen $X$, Wang Y. Adiponectin, an unlocking adipocytokine. Cardiovasc Ther. 2009 Spring;27(1)59-75. doi: 10.1111/j.1755-5922.2008.00069.x [Crossref] [PubMed][Google Scholar]
14. Robinson K, Prins J, Venkatesh B. Clinical review- adiponectin biology and its role in inflammation and critical illness. Crit Care. $2011 \mathrm{Apr}$ 20;15(2)221. doi: 10.1186/cc10021 [Crossref] [PubMed][Google Scholar]

15. Wang ZV, Scherer PE. Adiponectin, the past two decades. J Mol Cell Biol. 2016 Apr;8(2)93-100. doi: 10.1093/jmcb/mjw011 [Crossref][PubMed][Google Scholar]

16. Sharma K, Ramachandrarao S, Qiu G, Usui HK, Zhu $Y$, Dunn SR, et al. Adiponectin regulates albuminuria and podocyte function in mice. J Clin Invest. 2008;118(5)1645-56. doi: 10.1172/JCI 32691 [Crossref][PubMed][Google Scholar]

17. Rutkowski JM, Wang ZV, Park AS, Zhang J, Zhang D, Hu MC, et al. Adiponectin promotes functional recovery after podocyte ablation. J Am Soc Nephrol. 2013 Feb;24(2)268-82. doi: 10.1681/ASN.2012040414 [Crossref][PubMed] [Google Scholar]

18. de Boer IH, Sibley SD, Kestenbaum B, Sampson JN, Young B, Cleary PA, et al. Diabetes Control and Complications Trial/Epidemiology of Diabetes Interventions and Complications Study Research Group, Central obesity, incident microalbuminuria, and change in creatinine clearance in the epidemiology of diabetes interventions and complications study. J Am Soc Nephrol. 2007 Jan;18(1)235-43. doi: 10.1681/ASN.2006040394 [Crossref][PubMed][Google Scholar]

19. de Boer IH, Rue TC, Cleary PA, Lachin JM, Molitch ME, Steffes MW, et al. Diabetes Control and Complications Trial/Epidemiology of Diabetes Interventions and Complications Study Research Group, White NH, Danis RP, Davis MD, Hainsworth D, Hubbard LD, Nathan DM, Long-term renal outcomes of patients with type 1 diabetes mellitus and microalbuminuria: an analysis of the Diabetes Control and Complications Trial/Epidemiology of Diabetes Interventions and Complications cohort. Arch Intern Med. 2011 Mar 14;171(5)412-20. doi: 10.1001/archinternmed.2011.16

[Crossref] [PubMed][Google Scholar]

20. Intensive blood-glucose control with sulphonylureas or insulin compared with conventional treatment and risk of complications in patients with type 2 diabetes (UKPDS 33). UK Prospective Diabetes Study (UKPDS) Group. Lancet. 1998 Sep 12;352(9131)837-53. [Crossref][PubMed] [Google Scholar] 
21. Timothy C Evans, Peter C. Diabetic Nephropathy. Clinical Diabetes. 2000;18;7-46. [Crossref][PubMed][Google Scholar]

22. Fukami K, Yamagishi S, Ueda S, Okuda S. Role of AGEs in diabetic nephropathy. Curr Pharm Des. 2008;14(10):946-52.

doi:

10.2174/138161208784139710 [Crossref][PubMed] [Google Scholar]

23. Tziomalos K, Athyros VG. Diabetic NephropathyNew Risk Factors and Improvements in Diagnosis. Rev Diabet Stud. 2015 Spring-Summer;12(1-2)1108. doi: 10.1900/RDS.2015.12.110 [Crossref] [PubMed][Google Scholar]

24. Cao Z, Cooper ME. Pathogenesis of diabetic nephropathy. J Diabetes Investig. 2011 Aug 2;2(4)243-7. doi: 10.1111/j.20401124.2011.00131.x [Crossref][PubMed][Google Scholar]

25. Mezzano S, Aros C, Droguett A, Burgos ME, Ardiles $L$, Flores $C$, et al. NF-kappaB activation and overexpression of regulated genes in human diabetic nephropathy. Nephrol Dial Transplant. 2004 Oct;19(10)2505-12. doi: 10.1093/ndt/gfh207 [Crossref][PubMed][Google Scholar]

26. Dasu MR, Devaraj S, Park S, Jialal I. Increased toll-like receptor (TLR) activation and TLR ligands in recently diagnosed type 2 diabetic subjects. Diabetes Care. 2010 Apr;33(4)861-8. doi: 10.2337/dc09-1799 [Crossref][PubMed][Google Scholar]

27. Basi $S$, Fesler $P$, Mimran A, Lewis JB. Microalbuminuria in type 2 diabetes and hypertension- a marker, treatment target, or innocent bystander?. Diabetes Care. 2008 Feb;31 Suppl 2;S194-201. doi: 10.2337/dc08-s249 [Crossref][PubMed][Google Scholar]

28. Butler $A E$, Janson J, Bonner-Weir $S$, Ritzel $R$, Rizza RA, Butler PC. Beta-cell deficit and increased beta-cell apoptosis in humans with type 2 diabetes. Diabetes. 2003 Jan;52(1)102-10. doi: 10.2337/diabetes.52.1.102 [Crossref][PubMed] [Google Scholar]

29. Leahy JL, Hirsch IB, Peterson KA, Schneider D. Targeting beta-cell function early in the course of therapy for type 2 diabetes mellitus. J Clin Endocrinol Metab. 2010 Sep;95(9)4206-16. doi: 10.1210/jc.2010-0668 [Crossref][PubMed][Google Scholar]
30. Widjaja A, Stratton IM, Horn R, Holman RR, Turner R, Brabant G. UKPDS 20- plasma leptin, obesity, and plasma insulin in type 2 diabetic subjects. J Clin Endocrinol Metab. 1997 Feb;82(2)654-7. doi: 10.1210/jcem.82.2.3744 [Crossref][PubMed][Google Scholar]

31. Kopecký J, Flachs P, Bardová K, Brauner P, Prazák T, Sponarová J. Modulation of lipid metabolism by energy status of adipocytes: implications for insulin sensitivity. Ann N Y Acad Sci. 2002 Jun;967;88-101. doi: 10.1111/j.17496632.2002.tb04267.x [Crossref][PubMed][Google Scholar]

32. Okutan H, Ozcelik N, Yilmaz HR, Uz E. Effects of caffeic acid phenethyl ester on lipid peroxidation and antioxidant enzymes in diabetic rat heart. Clin Biochem. 2005 Feb;38(2)191-6. doi: 10.1016/j.clinbiochem.2004.10.003 [Crossref] [PubMed][Google Scholar]

33. Park $K$, Gross $M$, Lee $D H$, Holvoet $P$, Himes $J H$, Shikany JM, et al. Oxidative stress and insulin resistance: the coronary artery risk development in young adults study. Diabetes Care. 2009 Jul;32(7)1302-7. doi: 10.2337/dc09-0259 [Crossref][PubMed][Google Scholar]

34. Ouedraogo $\mathrm{R}$, Wu $\mathrm{X}$, Xu SQ, Fuchsel $\mathrm{L}$, Motoshima $\mathrm{H}$, Mahadev $\mathrm{K}$, et al. Adiponectin suppression of high-glucose-induced reactive oxygen species in vascular endothelial cellsevidence for involvement of a cAMP signaling pathway. Diabetes. 2006 Jun;55(6)1840-6. doi: 10.2337/db05-1174 [Crossref][PubMed][Google Scholar]

35. Yamauchi T, Kamon J, Ito $Y$, Tsuchida A, Yokomizo $\mathrm{T}$, Kita $\mathrm{S}$, et al. Cloning of adiponectin receptors that mediate antidiabetic metabolic effects. Nature. 2003 Jun 12;423(6941)762-9. doi: 10.1038/nature01705 [Crossref][PubMed][Google Scholar] 